\title{
TRPV1 Mediates Glucose-induced Insulin Secretion Through Releasing Neuropeptides
}

\author{
BEIHUA ZHONG ${ }^{1}$, SHUANGTAO MA ${ }^{1}$ and DONNA H. WANG ${ }^{1,2,3}$ \\ ${ }^{1}$ Division of Nanomedicine and Molecular Intervention, Department of Medicine, \\ ${ }^{2}$ Neuroscience Program, and ${ }^{3}$ Cell \& Molecular Biology Program, \\ Michigan State University, East Lansing, MI, U.S.A.
}

\begin{abstract}
Background/Aim: Transient receptor potential vanilloid 1 (TRPV1)-expressing sensory nerves innervate the pancreatic islets. Sensory neuropeptides, including calcitonin gene-related peptide (CGRP) and substance $P$ (SP), participate in insulin secretion. This study aimed to investigate the role of TRPVI in glucose-induced insulin secretion. Materials and Methods: TRPVI ${ }^{-1}$ and wild-type (WT) mice were fed a normal diet for 24 weeks. Glucose tolerance and insulin secretion were measured at the end of the experiments. Results: TRPV1 ${ }^{-1}$ mice had greater impairments in glucose tolerance and higher decrease in glucose-induced insulin secretion than WT mice. Capsaicin (a TRPVI agonist) increased insulin secretion in WT, but not in TRPVI ${ }^{-1-}$ mice. Glucose-induced insulin secretion was blunted in TRPVI mice, and was attenuated by AMG9810 (a TRPV1 inhibitor),

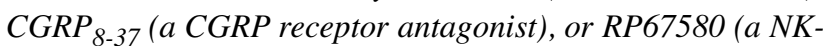
1 receptor antagonist) in WT mice. Glucose-induced SP and $C G R P$ release from WT pancreas was higher than that from TRPVI ${ }^{-1}$ pancreas. Conclusion: TRPVI mediates glucoseinduced insulin secretion likely through CGRP and SP release.
\end{abstract}

Transient receptor potential vanilloid 1 (TRPV1) is a nonselective cation channel and is predominantly expressed in sensory nerve fibers which innervate the pancreas (1). TRPV1-expressing pancreatic sensory nerves can release sensory neuropeptides, including calcitonin gene-related peptide (CGRP) and substance P (SP). Through sensation of surrounding glucose levels and subsequent release of CGRP

This article is freely accessible online.

Correspondence to: Donna H. Wang, Division of Nanomedicine and Molecular Intervention, Department of Medicine, Michigan State University, 788 Service Rd., East Lansing, MI 48824, U.S.A. Tel: +1 5174320797, e-mail: wangdo@msu.edu

Key Words: TRPV1, pancreas, insulin, substance P, calcitonin generelated peptide. and SP, sensory nerves may participate in the regulation of insulin secretion to maintain euglycemia. Although CGRP and SP have been linked to insulin secretion, the role of TRPV1 channels in glucose-induced insulin secretion is not clearly understood (2).

TRPV1 is activated by various stimuli and can be upregulated by high glucose levels (3-5). Activation of TRPV1 in the sensory nerves causes release of a number of neuropeptides, including CGRP and SP, and these peptides exert direct effects on islet hormone secretion (2, 6-8). In turn, insulin enhances TRPV1-mediated membrane currents, sensitizes TRPV1 function, and increases the release of CGRP (9). Capsaicin, a specific TRPV1 agonist, plays a role in glucose metabolism. However, the role of TRPV1 in insulin secretion is still controversial. Experiments with ablation of sensory nerves obtained various results. Karlsson et al. (10) have shown that depletion of capsaicin-sensitive sensory nerves increased glucose tolerance and glucose-induced early insulin secretion (10). However, Wall et al. (11) have reported that capsaicin-induced desensitization of TRPV1 decreased glucose-induced insulin secretion. Gram et al. (12) have reported that sensory nerve desensitization did not affect plasma insulin concentration in Zucker rats. Experiments with TRPV1 agonists obtained positive results. Akiba et al. (1) have shown that capsaicin dose-dependently increased insulin secretion and plasma insulin concentrations. Radu et al. have reported that a low dose of capsaicin reduced blood glucose levels in the late-phase of type 1 diabetes, with a partial reversal of the TRPV1 function by increasing the TRPV1 channel current density and recovery time (13). Tolan et al. (14) have shown that capsaicin enhanced glucose tolerance and elevated plasma insulin concentrations. Moreover, oral administration of N-oleoyldopamine, a selective TRPV1 agonist, elicited significant improvement in glucose tolerance (15). These findings suggest that TRPV1 may promote insulin secretion. However, the mechanism is still unknown.

In this study, we investigated the role of TRPV1 in glucoseinduced insulin secretion in both in vivo and in vitro experiments by using the TRPVl gene knockout (TRPV1 ${ }^{-/}$) mice. 


\section{Materials and Methods}

Animals. All experimental procedures were approved by the Michigan State University Animal Care and Use Committee and conform to NIH guidelines. TRPV1 ${ }^{-/-}$mice (B6.129S4TRPV $1^{\mathrm{tm} 1 \mathrm{Jul}}$ ) and WT mice on the genetic background of C57BL/6J were purchased from the Jackson Laboratory (Bar Harbor, ME, USA). Twenty-four-week-old male mice were fasted (without food but with water) for $15 \mathrm{~h}$, after which glucose $(2 \mathrm{~g} / \mathrm{kg}$ body weight) was administered to conscious mice by intraperitoneal injection (i.p.). Blood glucose levels at 0, 30, 60, 90 , and $120 \mathrm{~min}$ after glucose administration were measured using an Accu-Chek glucose meter (Roche Diagnostics). Tail vein blood was also collected at $0,30,60$, and $120 \mathrm{~min}$ for insulin determination. For measurement of acute insulin release, another group of mice were injected with glucose $(3 \mathrm{~g} / \mathrm{kg}$, i.p. $)$, and tail vein blood was collected at 2 to $14 \mathrm{~min}$ after glucose administration. Serum was immediately collected and stored at $-80^{\circ} \mathrm{C}$ for insulin determination. Insulin levels were measured using an ELISA kit (Crystal Chem, Downers Grove, IL, USA). The AUCs of insulin and glucose were calculated according to the trapezoidal rule. Glucose tolerance was defined as AUC versus time curve calculated with the trapezoidal rule. For studying the effects of capsaicin on insulin release and glucose tolerance test, another group of mice was fasted for $14 \mathrm{~h}$, tail vein blood was collected for basal blood glucose and insulin levels measurement. Then, capsaicin was administered $(0.25 \mathrm{mg} / \mathrm{kg}, i . p$. $)$, and tail vein blood was collected $1 \mathrm{~h}$ after capsaicin injection to measure insulin levels.

In Vitro insulin secretion. Mice were fasted for $15 \mathrm{~h}$ and anesthetized with pentobarbital sodium ( $50 \mathrm{mg} / \mathrm{kg}$ i.p. $)$, and their pancreases were dissected out. The tissue was washed with cold Krebs-bicarbonate buffer (KRB, $\mathrm{pH} 7.4$ ), containing (mmol/l) 118.5 $\mathrm{NaCl}, 4.7 \mathrm{KCl}, 1.2 \mathrm{MgSO}_{4}, 1.0 \mathrm{KH}_{2} \mathrm{PO}_{4}, 2.5 \mathrm{CaCl}_{2}, 25.0 \mathrm{NaHCO}_{3}$, supplemented with $1 \%(\mathrm{w} / \mathrm{v})$ bovine-serum albumin, $10 \mu \mathrm{g} / \mathrm{ml}$ aprotinin, $2 \mathrm{mmol} / \mathrm{l}$ glucose, and saturated with air. The tissue was minced into small pieces ( $2 \mathrm{~mm}$ in diameter) and then pre-incubated in $\mathrm{KRB}$ for $60 \mathrm{~min}$ at $37^{\circ} \mathrm{C}$ before being incubated with various substances or vehicle (16). To determine the effect of capsaicin on insulin release, capsaicin $\left(10^{-9} \mathrm{~mol} / \mathrm{l}\right)$, dissolved in vehicle consisting of Tween $80(10 \%)$ and ethanol $(10 \%)$ in $0.9 \% \mathrm{NaCl}$ (80\%), was added to KRB and incubated for $30 \mathrm{~min}$. To determine the role of TRPV1, CGRP, and SP in glucose-induced insulin release, AMG $9810\left(10^{-6} \mathrm{~mol} / 1\right.$, a selective TRPV1 antagonist), CGRP8-37 (10-6 M, a CGRP receptor antagonist), or RP67580 $\left(10^{-6} \mathrm{~mol} / \mathrm{l}\right.$, a selective neurokinin 1 receptor antagonist) was added $5 \mathrm{~min}$ before adding glucose $(8 \mathrm{mmol} / \mathrm{l})$. The incubation was stopped by chilling the samples in ice-cold water; aliquots were removed from the medium and stored at $-80^{\circ} \mathrm{C}$ for insulin assay. A commercial mouse insulin ELISA kit (Crystal Chem Inc., Downers Grove, IL, USA) was used to determine insulin release that was normalized to the wet pancreas weight.

Measurement of CGRP and SP. The samples were prepared as described above, purified, and analyzed by radioimmunoassay. The assay was performed as recommended by the supplier. Commercially available rat CGRP and SP radioimmunoassay kits (Peninsula Laboratories Inc.) were used for determination of SP and CGRP release which was normalized to the wet pancreas weight.
Statistical analysis. All values are expressed as mean \pm SEM. Differences among groups were compared by one-way analysis of variance followed by the Tukey-Kramer multiple comparison test. Differences between two groups were analyzed by $t$-tests. The results were considered statistically significant at $p<0.05$.

\section{Results}

Impaired glucose tolerance in TRPVI ${ }^{-1}$ mice. The experiments were conducted in $\mathrm{TRPV} 1^{-/-}$and wild-type (WT) mice at 24 weeks of age. No significant differences were observed between the two groups in body weight (WT $30.9 \pm 4.4 \mathrm{~g} v s$. TRPV1 $\left.{ }^{-/-} 32.6 \pm 4.7 \mathrm{~g}, p>0.05\right)$ and fasting glucose levels (WT $125 \pm 15 \mathrm{mg} / \mathrm{dl} v s$. TRPV1 $1^{-/-} 141 \pm 18$ $\mathrm{mg} / \mathrm{dl}, p>0.05$, Figure 1A). TRPV $1^{-/-}$mice had impaired glucose tolerance, with significantly higher blood glucose values at 30, 60 and $120 \mathrm{~min}$ after glucose challenge, compared with WT mice (Figure 1A). The overall area under the curve (AUC) of glucose was higher in TRPV1 ${ }^{-/-}$mice compared with WT mice (WT 390 $069 \mathrm{mg}$-hour/dl vs. $\mathrm{TRPV1}^{-/-} 534 \pm 45 \mathrm{mg}$-hour/dl, $p<0.01$, Figure 1B).

Decreased insulin secretion in TRPV1-/- mice. Fasting plasma insulin levels were similar between WT and TRPV1 ${ }^{-}$ ${ }^{/-}$mice (WT $0.34 \pm 0.12 \mathrm{ng} / \mathrm{ml} v s$. TRPV $1^{-/} 0.30 \pm 0.13 \mathrm{ng} / \mathrm{ml}$, $p>0.05$, Figure 1C). Plasma insulin levels, after glucose challenge, were not significantly different between the two groups at the individual time points of 30,60 , and $120 \mathrm{~min}$, but had a decreasing trend in TRPV1 ${ }^{-/-}$mice (Figure $1 \mathrm{C}$ ). Importantly, the AUC of insulin was lower in TRPV $1^{-/-}$ mice compared with WT mice (WT $1.50 \pm 0.30 \mathrm{ng}-\mathrm{h} / \mathrm{ml} v s$. TRPV $1^{-/} 1.07 \pm 0.43 \mathrm{ng}-\mathrm{h} / \mathrm{ml}, p<0.05$, Figure 1D), indicating that glucose-induced insulin secretion was impaired in TRPV $1^{-/-}$mice. Glucose-induced early-phase insulin secretion was observed at 4 minutes following glucose injection in WT mice but not in TRPV1 ${ }^{-1-}$ mice (Figure 2A), while insulin levels at $14 \mathrm{~min}$ after glucose injection were similar between WT and TRPV1 ${ }^{-/}$mice (Figure 2A). Plasma glucose levels were similar between the two groups at 2, 4, and 14 min after glucose administration (Figure 2B). These results suggested that the acute-phase insulin secretory response to glucose disappeared in $\mathrm{TRPV} 1^{-1-}$ mice. Furthermore, capsaicin (a TRPV1 agonist) caused a significant increase in insulin secretion in WT mice but not in TRPV $1^{-/-}$mice (Figure 3 ).

Decreased insulin secretion from TRPVI--- pancreases. Next, insulin release from isolated pancreases was measured in vitro. Upon high glucose stimulation, insulin secretion was increased in both WT and TRPV1 $1^{-/-}$ pancreases, with higher levels in WT compared to TRPV1I- pancreases $(p<0.05$, Figure $4 \mathrm{~A})$. Insulin release was increased in response to capsaicin stimulation in WT but not $\mathrm{TRPV}^{-/-}$pancreases (Figure 4B). Inhibition of 
A

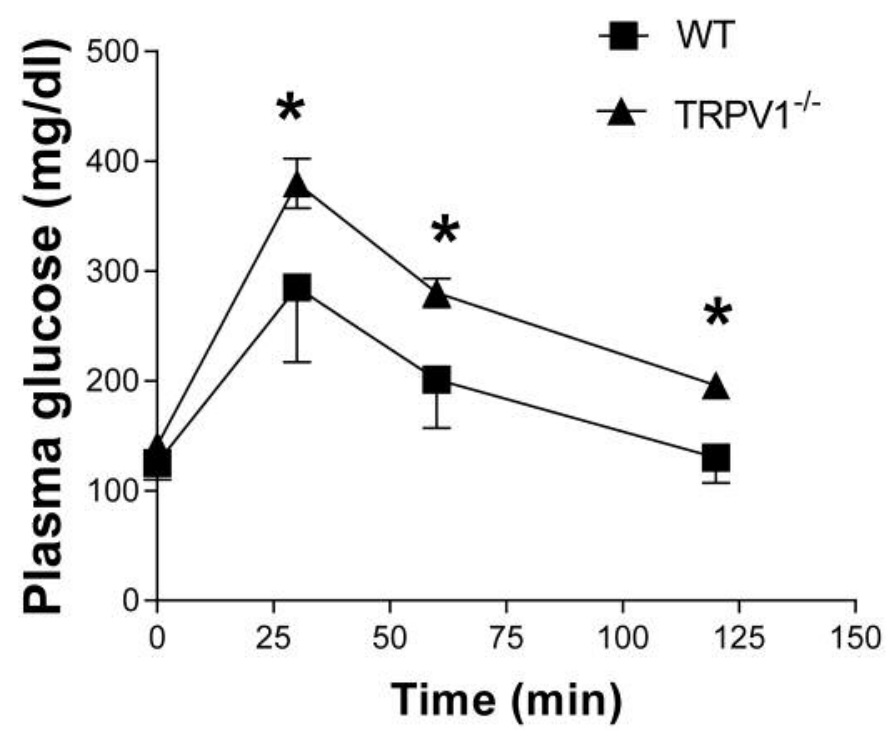

C

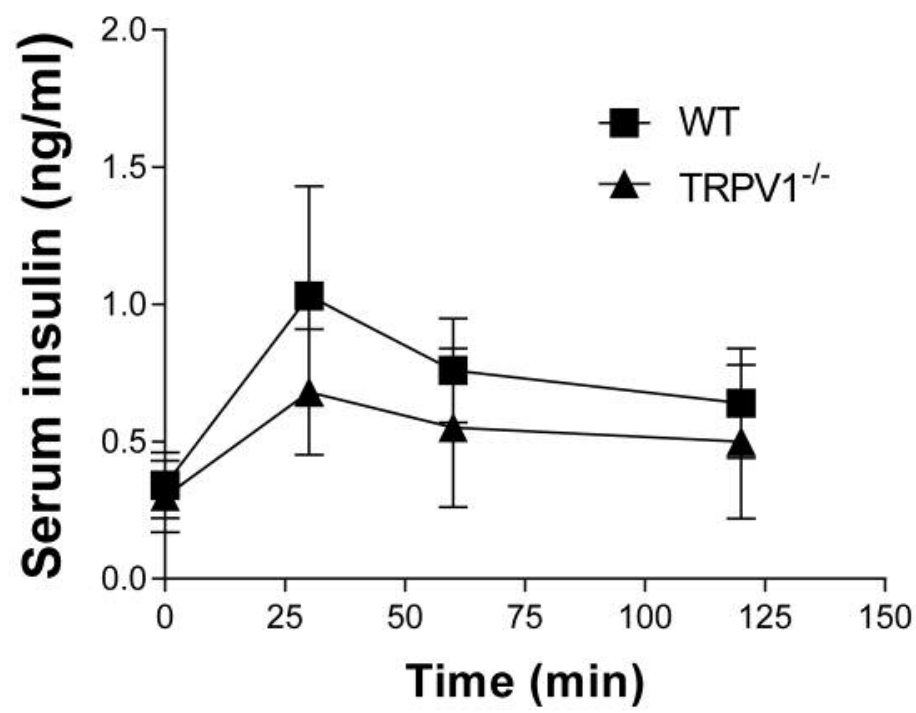

B

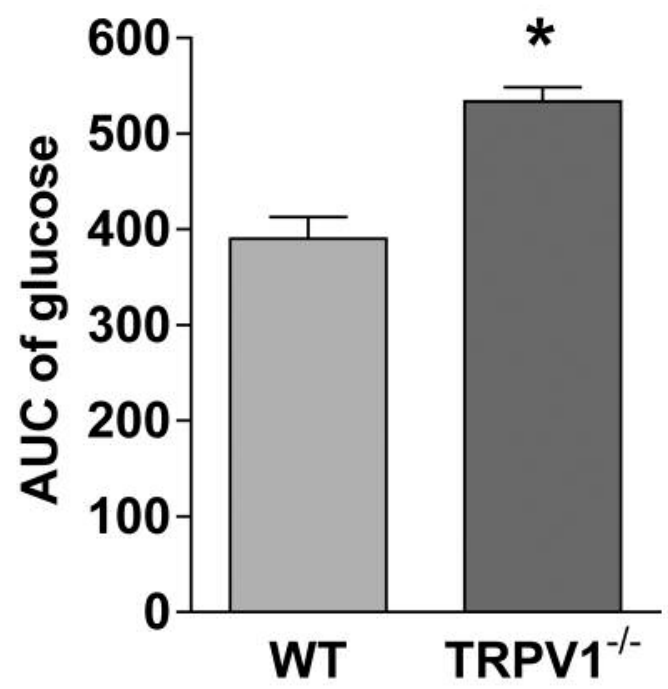

D

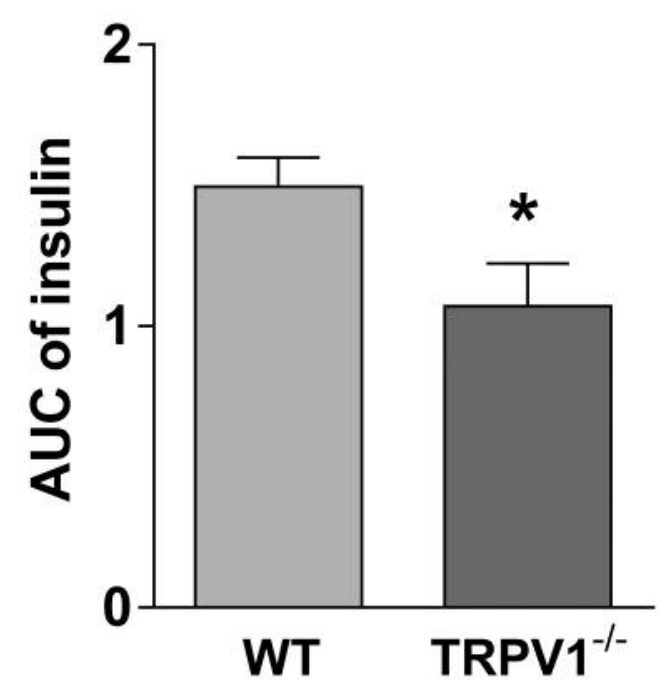

Figure 1. Glucose tolerance and insulin secretion of TRPV1-I- and WT mice. Plasma levels of glucose (A) and insulin (C) were measured in WT and TRPVI-I- mice before and after glucose injection $(2 \mathrm{~g} / \mathrm{kg}$ body weight, i.p.). Mean area under the curve (AUC) of glucose (B) and insulin (D) were calculated. Values are mean \pm SEM; $n=8-9 ; * p<0.05 \mathrm{vs}$. WT.

TRPV1, CGRP, or SP with AMG9810 $\left(10^{-6} \mathrm{M}\right.$, a selective TRPV1 antagonist), CGRP8-37 (10 ${ }^{-6} \mathrm{M}$, a selective CGRP receptor antagonist), or RP67580 $\left(10^{-6} \mathrm{M}\right.$, a selective NK1 receptor antagonist), respectively, abolished glucoseinduced insulin secretion in WT pancreases (Figure 4C), indicating that TRPV1, CGRP, and SP mediate glucoseinduced insulin secretion.
Impaired SP and CGRP release by TRPVI ${ }^{-/}$pancreases. The release of CGRP and SP at baseline was not different between WT and TRPV1 ${ }^{-/}$pancreases (Figure 5A and B). Upon high glucose stimulation, CGRP and SP release was remarkably increased compare to baseline in WT pancreas $(p<0.05)$, but was not increased in TRPV $1^{-/}$pancreases (Figure 5A and $\mathrm{B}$ ). 


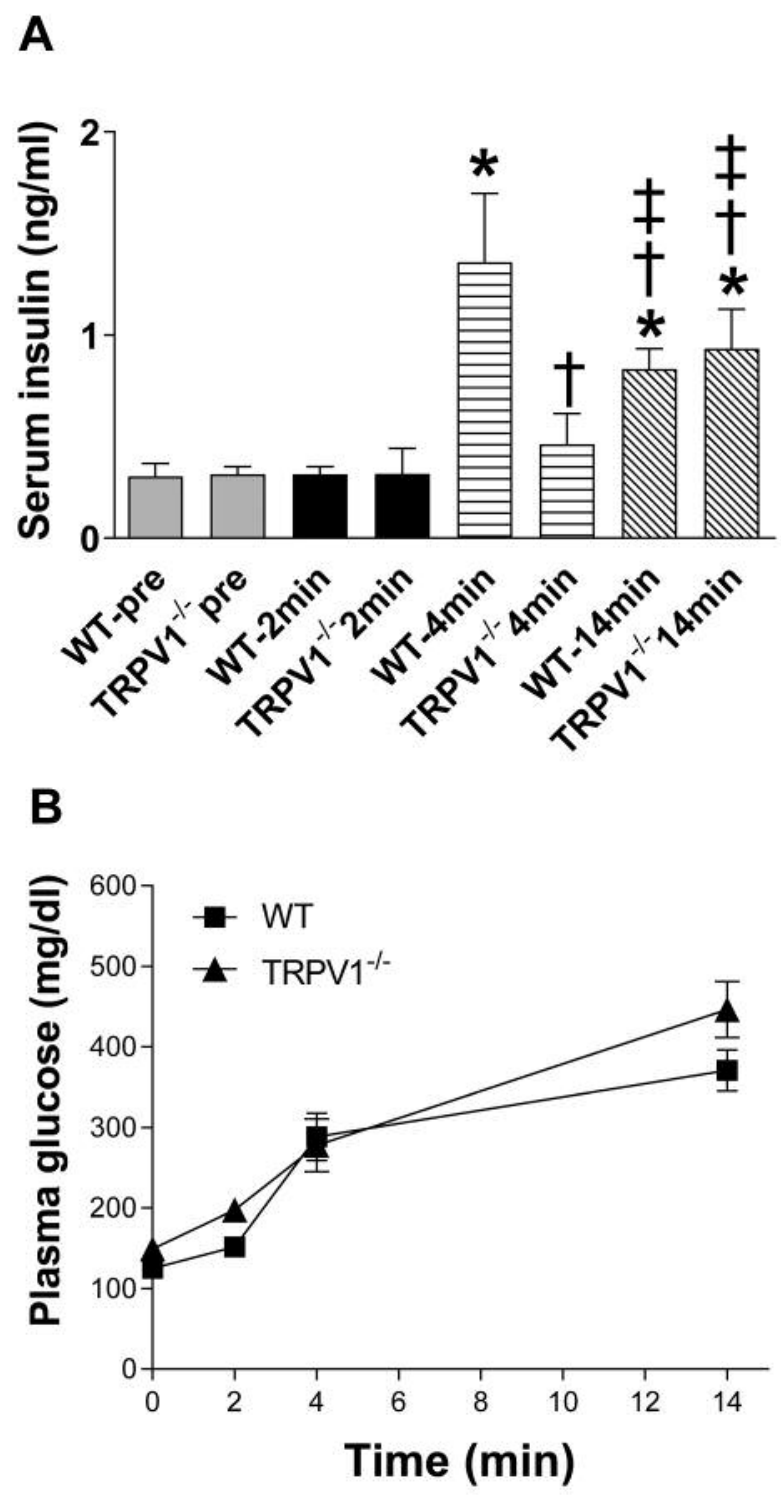

Figure 2. Acute phase insulin secretory response. Plasma levels of insulin (A) and glucose $(B)$ were measured in WT and TRPVI-I- mice before (pre) and at 2, 4, and 14 min after glucose injection ( $3 \mathrm{~g} / \mathrm{kg}$ body weight, i.p.). Values are mean \pm SEM; $n=5-8 ; * p<0.05 \mathrm{vs}$. WT-pre, TRPV1-l--pre, WT-2 min, TRPV1-l--2 min; ${ }^{\dagger} p<0.05$ vs. WT-4 min; ${ }^{ \pm} p<0.05$ vs. TRPV1-I--4 min.

\section{Discussion}

This study provides evidence that TRPV1 plays an important regulatory role in glucose-induced insulin secretion. Genetic ablation of TRPV1 resulted in impaired glucose-induced insulin secretion and glucose intolerance. It is interesting to highlight that the metabolic changes observed in TRPV1 ${ }^{-/}$ mice were different from previous reports obtained in experiments with sensory nerve desensitization by using

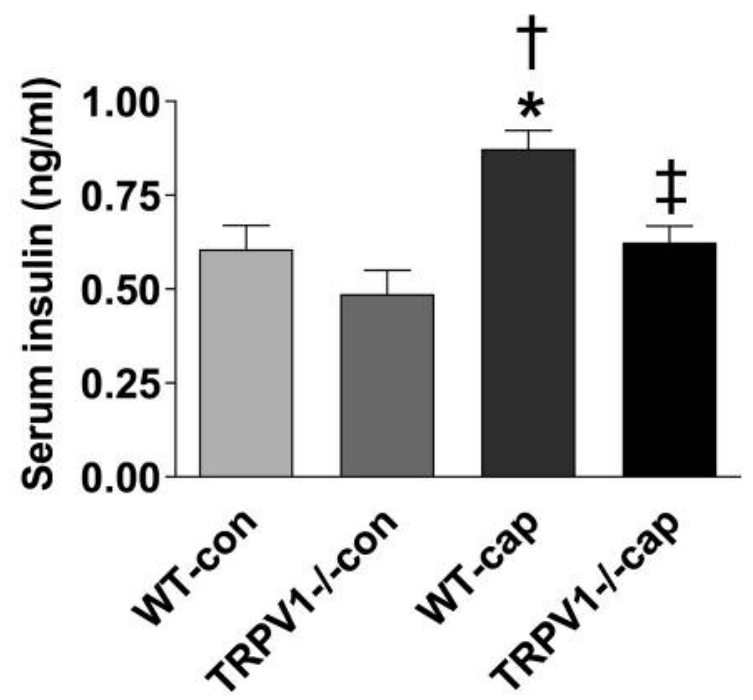

Figure 3. Effects of capsaicin on insulin secretory response. Plasma levels of insulin were measured in WT and TRPV1-1- mice before and after i.p. injection of capsaicin $(0.25 \mathrm{mg} / \mathrm{kg}$ body weight). Values are mean \pm SEM; $n=8$; * $p<0.05$ vs. WT-CON; ${ }^{\dagger} p<0.05$ vs. TRPVI-l-CON; $\sharp p<0.05$ vs. WT-cap.

resiniferatoxin or high doses of capsaicin (10). This inconsistency may be due to the fact that chemical denervation did not completely ablate the sensory nerves. The remaining sensory nerves may be sufficient to compensate through upregulating and sensitizing TRPV1 channels. This hypothesis is supported by previous studies showing that capsaicin pretreatment resulted in a significant upregulation of TRPV1 (17).

The present study showed that the first phase of insulin secretory response to glucose disappeared in TRPV $1^{-/-}$mice. Glucose induces a biphasic insulin secretion (18). Previous studies have shown that TRPV1-expressing sensory nerves innervate the pancreatic islets $(19,20)$. TRPV1 expression and function were decreased in high-glucose conditions and in obesity and diabetes (21). The first phase of insulin secretion is lost in obesity and diabetes (22). Present data showed that both WT and TRPV1 ${ }^{-/-}$pancreases had increased insulin secretion when glucose concentration was increased from 2 to $8 \mathrm{mmol} / \mathrm{l}$, while insulin secretion was higher in WT compared to TRPV1 $1^{-/-}$pancreases. Inhibition of TRPV1 with AMG 9810 inhibited glucose-induced insulin secretion in WT pancreases, indicating that TRPV1 mediates glucose-induced insulin secretion. The mechanism underlying the effects of TRPV1 on glucose-induced insulin secretion is largely unknown. A previous study has demonstrated that TRPV1 regulated glucose homeostasis through the induction of glucagon-like peptide-1 secretion from the gut (23). The present study focused on the role of neuropeptides released from pancreatic TRPV1-expressing sensory nerves. 
A

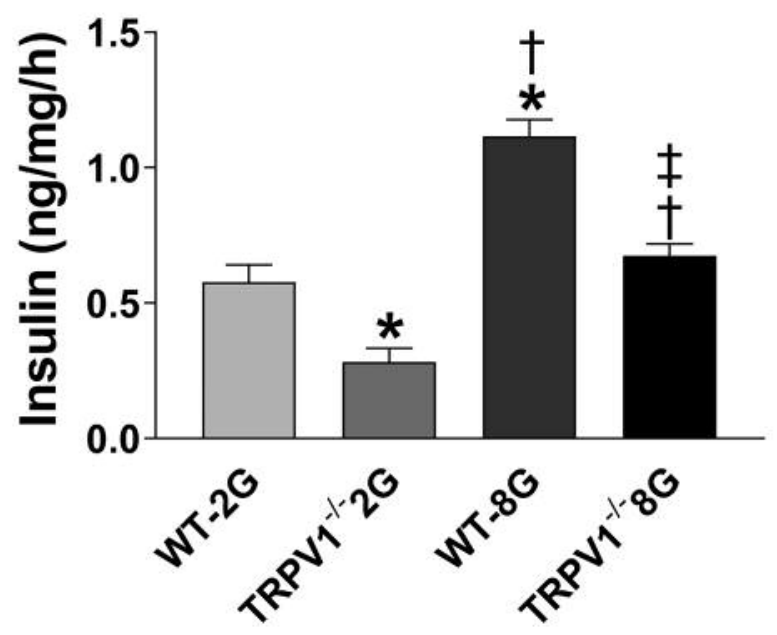

C

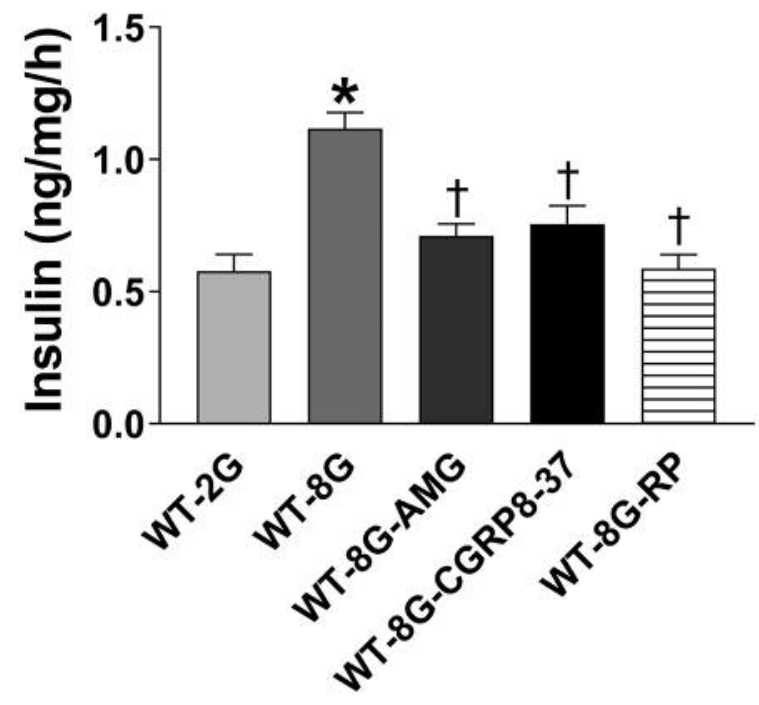

B

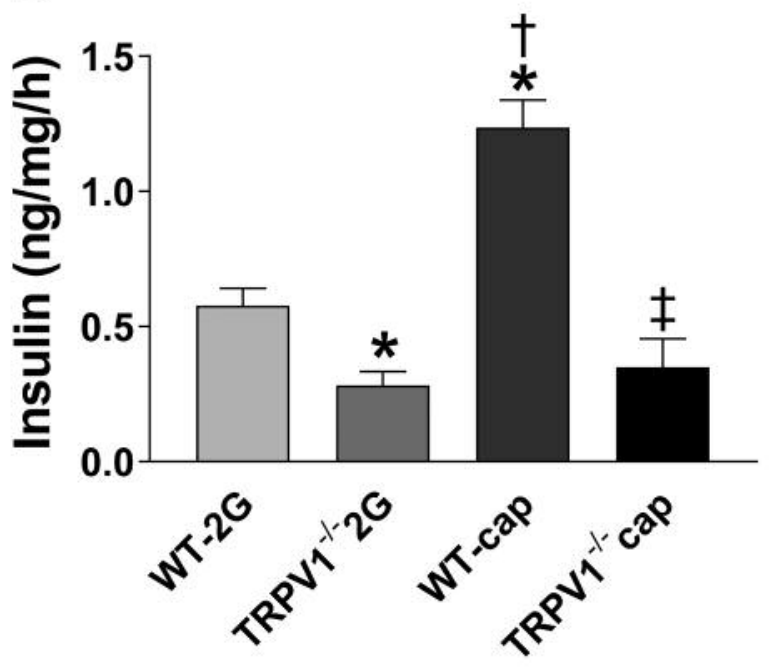

Figure 4. Glucose- and capsaicin-induced insulin secretion by pancreatic minces. Samples incubated in KRB medium containing $2 \mathrm{mmol} / \mathrm{l}$ glucose (2G) or $8 \mathrm{mmol} / \mathrm{l}$ glucose ( $8 G)(A)$, or capsaicin (cap) (B). (C) AMG9810 (AMG, a selective TRPV1 antagonist), CGRP8-37 (a selective CGRP receptor antagonist), or RP67580 (RP, a selective NK1 receptor antagonist) was added $5 \mathrm{~min}$ before adding glucose ( 8 mmol/l). Values are mean $\pm S E M ; n=4 ;{ }^{*} p<0.05 v s$. WT-2G; ${ }^{\dagger} p<0.05 \mathrm{vs}$. WT-8G (or TRPV1-I- 2G); ${ }^{\ddagger} p<0.05$ vs. WT-8G (or WT-cap).

CGRP has been identified in sensory nerve endings which innervate the pancreas (24). CGRP-like immunoreactivity has been demonstrated in pancreatic perivascular nerve fibers and in the islet insulin cells (25). However, the results on the effect of CGRP on insulin secretion are inconsistent $(6,26)$. Studies conducted by Rasmussen et al. have shown that CGRP at $10^{-10}$ and $10^{-9} \mathrm{~mol} / \mathrm{l}$ increased insulin and glucagon secretion from isolated, perfused porcine pancreas, whereas significant decreases were observed with $10^{-8} \mathrm{~mol} / \mathrm{l}$ (26). In contrast, Hermansen et al. have shown that CGRP inhibited insulin secretion at $10^{-10} \mathrm{~mol} / \mathrm{l}$, whereas stimulated insulin secretion at $10^{-9} \mathrm{~mol} / \mathrm{l}$, and the stimulation was marked and sustained at $10^{-8}$ $\mathrm{mol} / \mathrm{l}$ in the perfused dog pancreas (6). In many studies, CGRP was infused directly into the superior pancreatic artery at a low

dose rate. Given that CGRP is the most potent vasodilator agonist (27), infused CGRP might cause a severe fall in blood pressure. That might be the reason why insulin release was decreased. Our studies showed that glucose $(8 \mathrm{mmol} / \mathrm{l})$ increased insulin secretion from pancreases, and this effect was inhibited by the CGRP receptor antagonist. Radioimmunoassay also showed that the release of CGRP was higher in WT than in TRPV $1^{-/}$pancreases after stimulation with glucose, indicating that CGRP participates in glucose-induced insulin secretion.

SP may also be important in insulin secretion (28). Brown et al. (29) have shown that SP caused hypoinsulinemia, hyperglucagonemia, and hyperglycemia in rats. Fu et al. (30) have studied the effects of SP on insulin release from cultured rat islets, indicating that SP stimulated insulin 


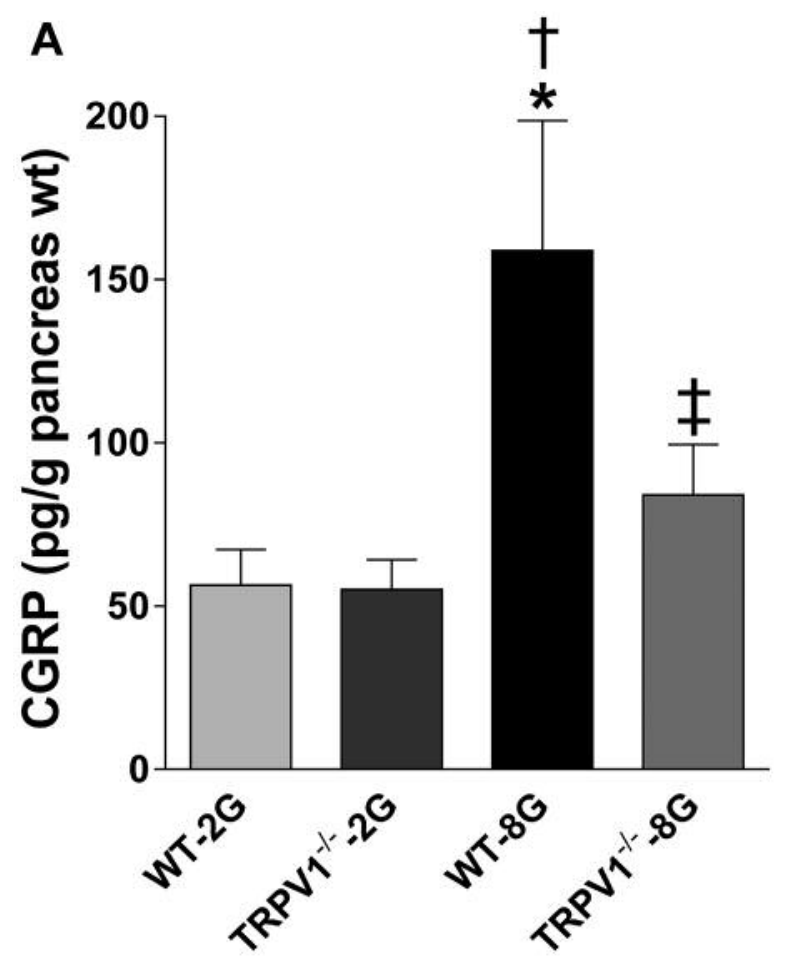

B

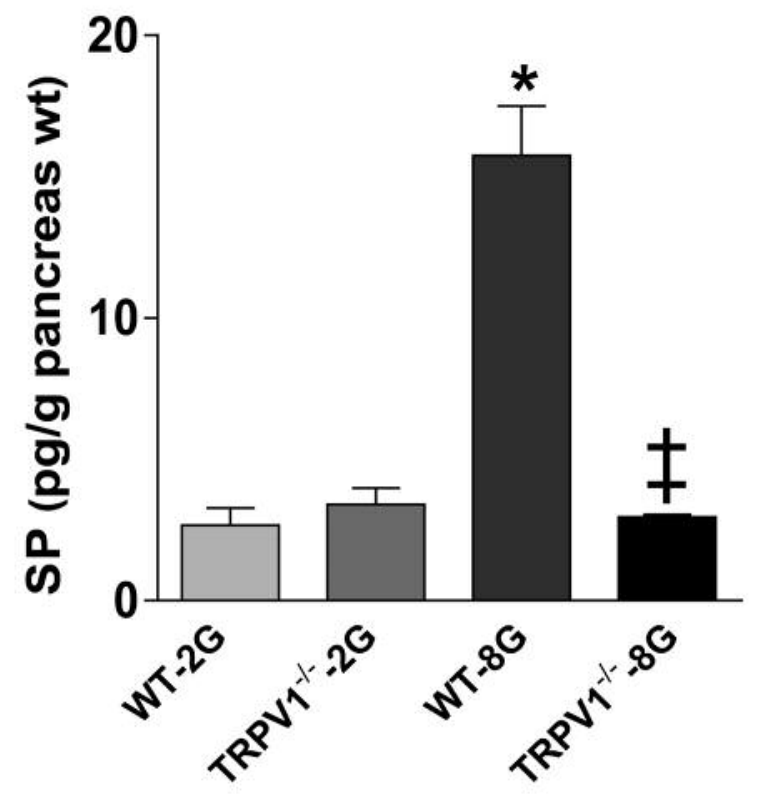

Figure 5. The release of CGRP (A) and SP (B) from isolated pancreases. Samples incubated in KRB medium containing 2 mmol/l glucose (2G) or $8 \mathrm{mmol} / \mathrm{l}$ glucose $(8 G)$. Values are mean $\pm S E M ; n=4 ;{ }^{*} p<0.05 \mathrm{vs}$. WT-2G; ${ }^{\dagger} p<0.05 \mathrm{vs}$. TRPVI ${ }^{-/-} 2 G ;{ }^{\ddagger} p<0.05 \mathrm{vs}$. WT-8G.

secretion in a dose-dependent manner. Hermansen et al. (8) have shown that SP increased insulin release in a dosedependent manner at high glucose conditions, but not at low glucose conditions. Moreover, Kaneto et al. have reported that endogenously released SP may stimulate insulin secretion (7). Chiba et al. (31) have studied the effects of SP on insulin release in rats and dogs under the same conditions. In rats, SP inhibited insulin secretion in a dosedependent manner. By contrast, in dogs, SP increased insulin secretion. These results demonstrated that the effects of SP on insulin secretion are dependent on species and glucose concentrations. Our studies showed that glucose increased insulin secretion from the pancreas, and this effect was attenuated by the NK1 receptor antagonist. Radioimmunoassay also showed that the release of SP was higher in WT than in TRPV1 ${ }^{-/}$pancreases after glucose stimulation. It is well established that activation of TRPV1 in sensory nerve endings stimulates SP release. Taken together, these findings suggest that SP mediates the effects of TRPV1 on glucose-induced insulin secretion.

\section{Conclusion}

In conclusion, our findings indicate that TRPV1 mediates glucose-induced insulin secretion likely through the release of CGRP and SP.

\section{Conflicts of Interest}

There are no conflicts of interest to declare regarding this study.

\section{Authors' Contributions}

BZ, DHW: conception and design, collection and/or assembly of data, data analysis and interpretation, and manuscript writing; SM: data interpretation and manuscript revision; BZ, SM, DHW: final approval of manuscript.

\section{Acknowledgements}

This work was supported in part by the National Institutes of Health (grants HL-57853, HL-73287, and DK67620).

\section{References}

1 Akiba Y, Kato S, Katsube K, Nakamura M, Takeuchi K, Ishii H and Hibi T: Transient receptor potential vanilloid subfamily 1 expressed in pancreatic islet beta cells modulates insulin secretion in rats. Biochem Biophys Res Commun 321: 219-225, 2004. PMID: 15358238.

2 Hiriart $\mathrm{M}$ and Aguilar-Bryan L: Channel regulation of glucose sensing in the pancreatic beta-cell. Am J Physiol Endocrinol Metab 295: E1298-1306, 2008. PMID: 18940941.

3 Caterina MJ, Leffler A, Malmberg AB, Martin WJ, Trafton J, Petersen-Zeitz KR, Koltzenburg M, Basbaum AI and Julius D: 
Impaired nociception and pain sensation in mice lacking the capsaicin receptor. Science 288: 306-313, 2000. PMID: 10764638. DOI: $10.1126 /$ science. 288.5464 .306

4 Julius D and Basbaum AI: Molecular mechanisms of nociception. Nature 413: 203-210, 2001. PMID: 11557989. DOI: $10.1038 / 35093019$

5 Lam D, Momeni Z, Theaker M, Jagadeeshan S, Yamamoto Y, Ianowski JP and Campanucci VA: RAGE-dependent potentiation of TRPV1 currents in sensory neurons exposed to high glucose. PLoS One 13: e0193312, 2018. PMID: 29474476. DOI: 10.1371/journal.pone. 0193312

6 Hermansen K and Ahren B: Dual effects of calcitonin generelated peptide on insulin secretion in the perfused dog pancreas. Regul Pept 27: 149-157, 1990. PMID: 1968674.

7 Kaneto A, Kaneko T, Kajinuma H and Kosaka K: Effects of substance $\mathrm{P}$ and neurotensin infused intrapancreatically on glucagon and insulin secretion. Endocrinology 102: 393-401, 1978. PMID: 743963.

8 Hermansen K: Effects of substance P and other peptides on the release of somatostatin, insulin, and glucagon in vitro. Endocrinology 107: 256-261, 1980. PMID: 6155261.

9 Van Buren JJ, Bhat S, Rotello R, Pauza ME, and Premkumar LS: Sensitization and translocation of TRPV1 by insulin and IGF-I. Mol Pain 1: 17, 2005. PMID: 15857517.

10 Karlsson S, Scheurink AJ, Steffens AB and Ahren B: Involvement of capsaicin-sensitive nerves in regulation of insulin secretion and glucose tolerance in conscious mice. Am J Physiol 267: R1071-1077, 1994. PMID: 7943418.

11 van de Wall EH, Gram DX, Strubbe JH, Scheurink AJ and Koolhaas JM: Ablation of capsaicin-sensitive afferent nerves affects insulin response during an intravenous glucose tolerance test. Life Sci 77: 1283-1292, 2005. PMID: 15939440 .

12 Gram DX, Hansen AJ, Wilken M, Elm T, Svendsen O, Carr RD, Ahren B and Brand CL: Plasma calcitonin gene-related peptide is increased prior to obesity, and sensory nerve desensitization by capsaicin improves oral glucose tolerance in obese Zucker rats. Eur J Endocrinol 153: 963-969, 2005. PMID: 16322403.

13 Radu BM, Iancu AD, Dumitrescu DI, Flonta ML and Radu M: TRPV1 properties in thoracic dorsal root ganglia neurons are modulated by intraperitoneal capsaicin administration in the late phase of type-1 autoimmune diabetes. Cell Mol Neurobiol 33: 187-196. PMID: 23111447.

14 Tolan I, Ragoobirsingh D and Morrison EY: Isolation and purification of the hypoglycaemic principle present in Capsicum frutescens. Phytother Res 18: 95-96, 2004. PMID: 14750210.

15 Chu ZL, Carroll C, Chen R, Alfonso J, Gutierrez V, He H, Lucman A, Xing C, Sebring K, Zhou J, Wagner B, Unett D, Jones RM, Behan DP and Leonard J: N-oleoyldopamine enhances glucose homeostasis through the activation of GPR119. Mol Endocrinol 24: 161-170. PMID: 19901198.

16 Coore HG and Randle PJ: Regulation of insulin secretion studied with pieces of rabbit pancreas incubated in vitro. Biochem $\mathrm{J}$ 93: 66-78, 1964. PMID: 5320084

17 Zvara A, Bencsik P, Fodor G, Csont T, Hackler L Jr., Dux M, Furst S, Jancso G, Puskas LG and Ferdinandy P: Capsaicinsensitive sensory neurons regulate myocardial function and gene expression pattern of rat hearts: a DNA microarray study. Faseb J 20: 160-162, 2006. PMID: 16278290.
18 Rorsman P, Eliasson L, Renstrom E, Gromada J, Barg S and Gopel S: The Cell Physiology of Biphasic Insulin Secretion. News Physiol Sci 15: 72-77, 2000. PMID: 11390882.

19 Riera CE, Huising MO, Follett P, Leblanc M, Halloran J, Van Andel R, de Magalhaes Filho CD, Merkwirth C and Dillin A: TRPV1 pain receptors regulate longevity and metabolism by neuropeptide signaling. Cell 157: 1023-1036, 2014. PMID: 24855942. DOI: 10.1016/j.cell.2014.03.051

20 Razavi R, Chan Y, Afifiyan FN, Liu XJ, Wan X, Yantha J, Tsui H, Tang L, Tsai S, Santamaria P, Driver JP, Serreze D, Salter MW and Dosch HM: TRPV1+ sensory neurons control beta cell stress and islet inflammation in autoimmune diabetes. Cell 127: 11231135, 2006. PMID: 17174891. DOI: 10.1016/j.cell.2006. 10.038

21 Sun J, Pu Y, Wang P, Chen S, Zhao Y, Liu C, Shang Q, Zhu Z and Liu D: TRPV1-mediated UCP2 upregulation ameliorates hyperglycemia-induced endothelial dysfunction. Cardiovasc Diabetol 12: 69, 2013. PMID: 23607427.

22 Del Prato $\mathrm{S}$ and Tiengo A: The importance of first-phase insulin secretion: implications for the therapy of type 2 diabetes mellitus. Diabetes Metab Res Rev 17: 164-174, 2001. PMID: 11424229.

23 Wang P, Yan Z, Zhong J, Chen J, Ni Y, Li L, Ma L, Zhao Z, Liu $\mathrm{D}$ and Zhu Z: Transient receptor potential vanilloid 1 activation enhances gut glucagon-like peptide-1 secretion and improves glucose homeostasis. Diabetes 61: 2155-2165, 2012. PMID: 22664955. DOI: $10.2337 / \mathrm{db} 11-1503$

24 Sternini C, De Giorgio R, Brunicardi FC, Widdison AL, Reber HA and Go VL: CGRP immunoreactivity in the mammalian pancreas. Ann NY Acad Sci 657: 487-490, 1992. PMID: 1637106.

25 Ahren B and Sundler F: Localization of calcitonin gene-related peptide and islet amyloid polypeptide in the rat and mouse pancreas. Cell Tissue Res 269: 315-322, 1992. PMID: 1423499.

26 Rasmussen TN, Bersani M, Schmidt P, Thim L, Kofod H, Jorgensen PN, Poulsen SS and Holst JJ: Isolation and molecular characterization of porcine calcitonin gene-related peptide (CGRP) and its endocrine effects in the porcine pancreas. Pancreas 16: 195-204, 1998. PMID: 9510144.

27 Brain SD and Grant AD: Vascular actions of calcitonin generelated peptide and adrenomedullin. Physiol Rev 84: 903-934, 2004. PMID: 15269340.

28 Schmidt PT, Tornoe K, Poulsen SS, Rasmussen TN and Holst $\mathrm{JJ}$ : Tachykinins in the porcine pancreas: potent exocrine and endocrine effects via NK-1 receptors. Pancreas 20: 241-247, 2000. PMID: 10766449.

29 Brown $\mathrm{M}$ and Vale W: Effects of neurotensin and substance P on plasma insulin, glucagon and glucose levels. Endocrinology 98: 819-822, 1976. PMID: 1261503.

$30 \mathrm{Fu}$ XW and Sun AM: Stimulative effect of substance P on insulin secretion from isolated rat islets under normobaric oxygen incubation. Zhongguo Yao Li Xue Bao 10: 69-73, 1989. PMID: 2479220.

31 Chiba Y, Kawai K, Okuda Y, Munekata E and Yamashita K: Effects of substance P and substance P-(6-11) on hormone release from isolated perfused pancreas: their opposite actions on rat and canine islets. Endocrinology 117: 1996-2000, 1985. PMID: 2412802.

Received June 5, 2019

Revised June 28, 2019

Accepted July 3, 2019 